Burnout' (Bulletin, March 1984, 8, 45-46) interesting in its importation of American terms for deteriorating activity without the American attitude to the environmental factors involved. Dr Mackarness is known for his approach to food in mental illness, ${ }^{\prime}$ but his real insight was in recognizing the illness from everyday contacts with chemicals. ${ }^{2}$ The victims are not aware of the cause of their upset as they briefly feel well before weakening on coming in contact once more with the compound (anything from tobacco smoke and perfume, to 'out gassing from paint').

Psychiatrists with the skill and application to cope with psychotherapy would be able to select those patients sent to them with vague loss of energy, disturbance of activity and wellbeing who could, by altering their diet, surroundings and expectations, learn to live in a world that had begun to harm them physically. Many patients (and doctors too) will be unable to accept the possibility that their palpitations occur on scenting the propellant from a spray can, while the possibility that their upset is from food eaten every day of their life seems unreal ('masked allergy'). Elimination, diversified rotated, fungus reducing diets with 'drops' to help the severely crippled can produce remarkable improvements in the sophisticated patient, the vast bulk of psychiatric clinics will have to continue to smoke and lean on medication, living in houses that cook with gas, using 'potable' water.

Perhaps sometime, you will publish a study involving clinical ecology, allergy or the effect of failure in the immune system to cope with stress.

D. G. MAYNE

Area Hospital

Craigavon, $N$. Ireland

REFERENCES

'Mackarness, R. (1976) Not All in the Mind. London: Pan. 2 (1980) Chemical Victims. London: Pan.

\section{Psychiatric monitoring of Standards Committee Dear Sirs}

The Standards Committee was set up here in 1975 to monitor the aims and standards of provisions and care, with particular reference to the elderly, mental illness and mental handicap. It meets monthly and has the same chairman as the Division of Psychiatry. In addition, there is a three monthly multidisciplinary meeting to provide an open forum which all members of the Department can attend.

Regularly attending members include the four consultant psychiatrists, three members of the District Health Committee, a junior psychiatrist representative, one of the rotating University MRCPsych trainees, the District Community Medical Officer of Health, the Principal Psychologist, the Director of Psychiatric/Geriatric Nursing Services, the Group Assistant Director of Nursing, the Senior Nurse Managers, the Senior Nurse Manager (Night Duty), and the Unit Administrators.

The discussions carried out are thorough and the 'workthrough time' is usually less than an hour and a half, with each item numbered from month to month to facilitate cross-referencing, and the heading 'Action' used for individuals or groups to pursue relevant matters further.

The meetings have led to useful abreactive and productive discussion, acceptance of the rights and significance of attending contributors, cross-fertilization of ideas (both for improvements and prevention of avoidable difficulties and hazards) and, not least, involvement of the lay members who volunteer their appreciation and enhance insight into the practical workings and difficulties of our Department. Thereafter they are more able to represent these views when the Minutes are considered by the District Health Authority and Team and the Mental Illness Panel. This involvement with informative feedback helped regarding allocation of resources, continued integration into the District General Hospital and Group functioning, and has furthered practical and public relations. It has also been encouraging to see how the assemblies have brought out both the positive qualities and contributions of previously reticent participants, and by a 'round table' approach, the positive aspects and often warm relationships and practical results developed over the greater part of a decade of functioning. It is hoped that this information, adapted as appears appropriate, might be of help to others.

Halifax General Hospital

Montague Segal

Halifax, West Yorks

\section{Obituary}

Charles Booth Robinson, retired, former Medical Superintendent, Purdysburn Hospltal, Belfast.

Charlie Robinson, a Foundation Fellow of the College, died on 11 March 1984. He had been Consultant Psychiatrist and Medical Superintendent at Purdysburn Hospital from 1950 to 1969. He had also been consultant to the Royal Victoria Hospital, Crumlin Road Prison, Malone Training School and the Ministry of Pensions. From 1969 to 1972 he was Senior Medical
Officer and Psychiatric Adviser to the Ministry of Health and Social Services in Northern Ireland, but had to fully retire due to ill health and with his wife made his home in the Wirral Peninsula.

Born at Newry, Co. Down on 26 April 1912, he was educated at Wesley College and Trinity College, Dublin. He was one of four brothers and a sister who qualified in medicine. Charlie Robinson was an example in many ways during his life, but 
notably for his dogged but always cheerful determination in overcoming the handicap of tuberculosis and consequent radical surgery. In 1933, in the middle of his student life, he had a complete left thoracoplasty followed by other operations. After three years in Switzerland he resumed his medical studies to graduate MB, ChB, BAO with honours in 1939 with first prize in surgery and jointly the Adelaide Hospital Hudson prize.

He rose in standing in the province from Medical Officer in Purdysburn Hospital in 1939 to become a torch bearer and spokesman for psychiatry. Despite increasing administrative work he maintained his teaching and examining interests, witness to which are the many consultant psychiatrists whom he examined for membership of the Royal College of Physicians of Ireland, having himself become a member in 1942 and fellow in 1948. He was an active member of many committees and chairman of not a few, including the Irish branch of the Royal Medico-Psychological Association. His practice of psychiatry showed his eclectic approach to the subject. Charlie was an inspiration to all. He, and we, his many friends left behind, found great pleasure that his son, Arthur, followed in his father's footsteps to become a consultant psychiatrist in northeast England.

W. A. G. MACC

Robert Wyndham Tibbetts, formerly Consultant Psychiatrist, United Birmingham Hospitals (Central Birmingham Health District), Birmingham, West Midlands.

Dr R. W. Tibbetts, known to all his friends and colleagues as Peter, died in the Queen Elizabeth Hospital, Birmingham, on 26 May 1984 at the age of 69.

He was born on 12 December 1914 at Old Hill, Staffordshire, the son of a general practitioner. After attending Bromsgrove School he went up to Christ Church, Oxford, to undergo his preclinical training, where he obtained 2nd Class Honours in Physiology. He returned to Birmingham for his clinical years, graduating in Medicine from Oxford in 1939; then, following a house physician's appointment, obtained a post in neuropsychiatry at Bromsgrove EMS Hospital.

He joined the RAMC in 1941 and in due course served for two years with the Chindits in Burma. He was promoted major and mentioned in despatches. Returning to civil life in 1946 he underwent postgraduate training in psychiatry, firstly as a registrar at the Maudsley Hospital, then as first assistant in the Psychiatric Department at St George's Hospital with Professor Desmond Curran. After holding two appointments as Assistant Psychiatrist (SAMO) at Wimbledon Hospital and at Graylingwell, he was appointed Consultant Psychiatrist to the United Birmingham Hospitals, which position he held until his retirement in 1978. He was also Consultant Psychiatrist to the Midland Centre for Neurosurgery, the Birmingham Medical Institute for the Blind and for many years undertook a weekly session at the Birmingham Children's Hospital. He was a senior clinical lecturer in the Birmingham University Department of Psychiatry and a most valued member of its teaching staff. He was also an examiner for the MRCPsych.
Although his published research output was not large- he was too busy in many other ways for that-he made interesting and sensible contributions to the literature on anorexia nervosa. the placebo response and on his investigations into the aetiology of awkward and disabling neuromuscular disorders such as spasmodic torticollis and writer's cramp. However, it will be as a teacher and a clinician that Peter will best be remembered by his friends, colleagues and students alike. Indeed, when it was his turn to undertake a case presentation this was an occasion not to be missed. These presentations were characterized not only by thoroughness and skill but also by a touch of panache, never overdone, but betraying perhaps his genuine love of the theatre. Thus if, as usual, they happened to entertain as well as to inform, this could be regarded as a bonus which, like a good illustration, serves to emphasize the message which it is intended to convey. He also retained a remarkable 'Professor Higgins-like' talent for identifying, from the manner in which they spoke, where his patients were born and brought up, being often able to narrow this down to a very small area of the Black Country or elsewhere, a feat which never ceased to impress his audience.

As a clinician he was the undoubted possessor of the most important qualities of a good physician: clinical acumen, an enquiring mind, patience, humanity and, above all, great sympathy with his patients and their problems. As a sure-handed diagnostician his opinion was widely sought and justifiably so. If challenged in his judgement-and this was a rare event-it took a very closely reasoned argument to make him change his mind, although this could never be attributed to innate inflexibility, for he was ever ready to hear and consider other opinions.

Apart from his professional qualities, Peter was a good and loyal friend with a keen sense of humour. He was also a most convivial host so that an evening in the company of he and his wife at their lovely home in Elmley Castle was a pleasure not to be denied. He took a great interest in the village and in its church and was for many years President of the local cricket club. He was a great gardener so that his herbaceous border at the right time of year became a magnificent display. He was also a keen forester and owned a sizeable stretch of woodland not many miles from his home.

WHT

Peter Tibbetts was my colleague and friend for 25 years. During that time he worked like a Trojan helping to build a psychiatric department in the Birmingham Teaching Hospitals.

After war service in the RAMC, he specialized in psychiatry at St George's Hospital, London, and was appointed Consultant Psychiatrist to the United Birmingham Hospitals. With very limited resources and without the cachet of an 'academic unit' the department developed and attracted some of the finest recruits to psychiatry in the land and from elsewhere. There are now many distinguished psychiatrists all over the world who will grieve over his passing and reflect with nostalgic pleasure over their association with him.

He loved teaching and was very good at it. His wit, humour 